\title{
Infliximab reduces Zaprinast-induced retinal degeneration in cultures of porcine retina
}

\author{
Cristina Martínez-Fernández de la Cámara', Lorena Olivares-González', David Hervás², David Salom³, \\ José M Millán ${ }^{1,4,5}$ and Regina Rodrigo ${ }^{1,4,6^{*}}$
}

\begin{abstract}
Background: CGMP-degrading phosphodiesterase 6 (PDE6) mutations cause around 4 to 5\% of retinitis pigmentosa (RP), a rare form of retinal dystrophy. Growing evidence suggests that inflammation is involved in the progression of RP. The aims of this study were to corroborate the presence of high TNFa concentration in the eyes of RP patients and to evaluate whether the blockade of TNFa with Infliximab, a monoclonal anti-TNFa antibody, prevented retinal degeneration induced by PDE6 inhibition in cultures of porcine retina.

Methods: Aqueous humor from 30 patients with RP and 13 healthy controls were used to quantify the inflammatory mediators IL-6, TNFa, IL-1 $\beta, I L-10$ by a multiplex enzyme-linked immunosorbent assay (ELISA) system. Retinal explants from pig were exposed to Zaprinast, a PDE6 inhibitor, for 24 hours in the absence or the presence of Infliximab. Cell death was evaluated by TUNEL assay. The number and distribution of caspase-3 positive cells, indirect poly(ADP)ribose polymerase (PARP) activation and glial fibrillary acidic protein (GFAP) content were visualized by immunolabeling. Antioxidant total capacity, nitrites and thiobarbituric acid reactive substances (TBARS) formation were determined to evaluate antioxidant-oxidant status.
\end{abstract}

Results: IL-6 and TNFa concentrations were higher in the aqueous humor of RP patients than in controls. Infliximab prevented retinal degeneration, as judging by the reduced presence of TUNEL-positive cells, the reduction of caspase-3 activation and also reduction of glial activation, in an ex vivo model of porcine retina. Additionally, Infliximab partially reduced oxidative stress in retinal explants exposed to Zaprinast.

Conclusions: Inflammatory mediators IL-6 and TNFa were elevated in the aqueous humor of RP patients corroborating previous studies suggesting sustained chronic inflammation. Our study suggests that TNFa is playing an important role in cell death in an ex vivo model of retinal degeneration by activating different cell pathways at different cell layers of the retina that should be further studied.

Keywords: Retinal degeneration, Inflammation, Infliximab, Oxidative stress, TNFa, Poly(ADP-ribose), caspase-3, Retinitis pigmentosa, Photoreceptor death

\section{Background}

Retinitis pigmentosa (RP) is a common form of rod-cone dystrophy, constituting the largest Mendelian genetic cause of blindness in the developed world. Patients with RP typically loose night vision in adolescence, peripheral vision in young adulthood, and central vision later in life due to progressive loss of rod and cone photoreceptor cells. Photoreceptor cell death starts with rod photoreceptor

\footnotetext{
* Correspondence: regina.rodrigo@yahoo.es

'Sensorineural Disorders, Health Research Institute-La Fe, Valencia, Spain

${ }^{4}$ Centre for Biomedical Network Research on Rare Diseases (CIBERER), Madrid, Spain

Full list of author information is available at the end of the article
}

degeneration and eventually cone cell death that is the major problem affecting RP patients, because it leads to loss of central vision [1]. More than 60 genes, including phosphodiesterase 6 (PDE6) subunit genes, have been identified to date that, when mutated, cause different forms of non-syndromic RP [2-7].

Although RP is a genetic disease, increasing evidence in patients and animal models suggests that oxidative stress and inflammation, especially TNF $\alpha$, contribute to its pathogenesis, independently of the genes mutated [8-10]. Some reports show the presence of sustained chronic inflammatory reaction including elevated TNF $\alpha$ 
levels in the eyes of RP patients [11] and $r d 10$ mice [12]. TNF $\alpha$ is a pleiotropic cytokine essential for the induction and maintenance of the inflammatory immune responses [13] that is also upregulated in inflammatory ocular diseases, including Adamantiades-Behcet disease [14], retinal vascular tumors [15], neovascular age-related macular degeneration [16], uveitis [17], glaucoma [18] and ischemic retinopathy [19].

TNF $\alpha$ mediates a broad range of cellular activities, including proliferation, survival, differentiation, inflammation and cell death. In the retina, TNF $\alpha$ is likely to be secreted from activated macrophages, astrocytes, microglial cells and retinal Müller glial cells. TNF $\alpha$ can trigger several well-characterized death-promoting (caspase-dependent and caspase-independent cell death) and survival-promoting pathways, depending upon the predominating signaling pathway in the particular cell type [20]. TNF $\alpha$ binding to cell surface receptors such as TNFR1 mediates activation of initiator caspases (caspase-8, caspase-10) and finally triggers cleavage of effector caspases (extrinsic pathway of cell death) [21]. TNF $\alpha$ is also involved in the intrinsic pathway of cell death that is initiated by cellular and DNA damage which particularly involves mitochondria. Finally, TNF $\alpha$ can also activate a subset of programmed necrosis called necroptosis. The mechanism that leads cells to undergo apoptosis or necroptosis and the mechanism that mediates the execution of necroptosis still remains unclear. The poly(ADP-ribose) polymerase (PARP) pathway can also activate this mode of programmed necrosis. PARP-1 activation in response to excessive DNA damage results in the massive synthesis of poly(ADP-ribose) polymers (PAR), $\mathrm{NAD}^{+}$depletion and subsequent release of apoptosis inducing factor (AIF) from mitochondria, which translocates to the nucleus where it forms an active DNA-degrading complex (caspase-independent pathway). The PARP pathway has been considered as an integral part of TNF-induced necroptosis; however, it has been recently described that both pathways represent distinct and independent routes to programmed necrosis [22].

The mechanisms responsible for photoreceptor cell death in RP are still unclear. However, increasing evidence suggests that inflammation [11,12,23,24] and especially TNF $\alpha$ could contribute to the pathogenesis of RP. Therefore, inhibition of TNF $\alpha$ and downstream cellular signaling mechanisms, following interaction of TNF $\alpha$ with its receptors, could be a possible target in the treatment of retinal neurodegenerative disorders such as RP.

In the current study we found that IL- 6 and TNF $\alpha$ were increased in the aqueous humor of RP patients. We also observed that pharmacological inhibition of TNF $\alpha$ with Infliximab, a specific monoclonal antibody against TNF $\alpha$, prevented retinal degeneration in cultures of porcine retina exposed to Zaprinast. This model reproduces some events of the degeneration found in murine models of RP caused by non-functional PDE6 [25]. We also observed in our model a reduction of caspase-3 activation, GFAP reactivity and partially oxidative stress, caused by Infliximab treatment. These results suggest that inflammation, especially TNF $\alpha$ upregulation, is playing an important role in retinal degeneration and, importantly, that strategies that promote its blockade could be promising therapies.

\section{Methods}

\section{Participants in the study}

Human samples were obtained, informed consent from all subjects previously having been given. The procedure was in accordance with the tenets of the Declaration of Helsinki and was approved by the IRB of La Fe University Hospital (Valencia, Spain). Thirty adult patients with typical forms of RP characterized by an elevated final dark-adaptation threshold, retinal arteriolar narrowing, and a reduced and delayed electroretinogram were enrolled in the study. Thirteen Caucasian patients suffering from cataracts without any other ocular disease served as controls. Further details of the patients enrolled in the study are shown in Table 1.

Patients diagnosed of RP were recruited from Retina Comunidad Valenciana - Asociación Afectados por Retinosis Pigmentaria and also from the department of Ophthalmology of La Fe University Hospital (Valencia, Spain). Healthy controls were recruited from $\mathrm{La} \mathrm{Fe}$ University Hospital (Valencia, Spain).

\section{Ophthalmic examination}

The best-corrected visual acuity (BCVA) and automated visual field (VF) were measured in RP patients as previously described [8]. Individual data for each patient is shown in Additional file 1: Table S1. Macular edema secondary to RP was only present in one patient.

\section{Aqueous humor extraction}

Aqueous humor samples from $30 \mathrm{RP}$ patients and from 13 patients with cataracts without any other ocular disease (controls) were collected as previously described [8]. Undiluted aqueous humor samples were collected from each patient, placed in sterile tubes, and stored immediately at $-80^{\circ} \mathrm{C}$ until use. All specimens were assayed to evaluate cytokine concentration in a double-blind arrangement with respect to their group. For each patient,

Table 1 Description of the participants included in the study

\begin{tabular}{lll}
\hline & Control & RP \\
\hline Number of subjects & 13 & 30 \\
Males & 7 & 21 \\
Females & 6 & 9 \\
Age (years) & $60 \pm 3$ & $48 \pm 2$ \\
\hline
\end{tabular}


aqueous humors were collected from the eye with the more severe retinopathy.

\section{Cytokine levels in aqueous humor}

The concentrations of cytokines in aqueous humor were measured using a multiplex enzyme-linked immunosorbent assay (ELISA) system. To measure the concentrations of IL-1 $\beta$, IL-6, IL-10 and TNF $\alpha$, the SearchLight Custom Human Cytokine-Inflammation Q-Plex Array (Aushon Biosystems, MA, USA) was used. Array was used according to the manufacturer's instructions. The signal of the cytokine array was determined by a cooled CCD camera (Fujifilm, Tokyo, Japan) using chemiluminescence. SearchLight CCD Imaging and Analysis System were used to quantify cytokine concentrations. The cytokine levels were expressed as $\mathrm{pg} / \mathrm{mL}$.

\section{Porcine retinal explant cultures}

Seventy eyes (both left and right eyes from each animal) from small miniature pigs aged 3 to 7 months were obtained from the local slaughterhouse. Neuroretinal explants were carried out as recently described [25]. Treatments were added the day of the culture and maintained for 24 hours. To inhibit PDE6 and induce retinal degeneration, we used a final concentration of $100 \mathrm{nmol} / \mathrm{L}$ Zaprinast [25,26]. Zaprinast (Sigma-Aldrich, Madrid, Spain) was diluted in dimethyl sulfoxide (DMSO) (AppliChem, Darmstadt, Germany). The equivalent amount of DMSO was added to the culture medium of controls. To evaluate the possible neuroprotective effect of TNF $\alpha$ blockade we used Infliximab $(2 \mu \mathrm{g} / \mathrm{mL}$, alone or combined with Zaprinast) as TNF $\alpha$ blocker (Remicade ${ }^{\circledR}$, Schering-Plough, Madrid, Spain). Infliximab is a chimeric human immunoglobulin G1 with a mouse variable fragment having high TNF $\alpha$ affinity and neutralizing capacity.

\section{Tissue processing and histology}

Retinal explants were fixed in 4\% filtered paraformaldehyde (Sigma-Aldrich, Madrid, Spain) in 0.1 M PBS (pH 7.4) and cryoprotected in a saccharose gradient (15-20-30\%) (Panreac Química, Barcelona, Spain). Samples were frozen embedded in Tissue-Tek ${ }^{\oplus}$ OCT $^{\mathrm{Tm}}$ Compound (Sakura Finetek Europe BV, Zoeterwoude, The Netherlands). After this, $10-\mu \mathrm{m}$ sections were cut with a cryostat (Leica CM1900, Nussloch, Germany) and placed on Super Frost Ultra Plus treated slides (Thermo Scientific, Barcelona, Spain).

\section{TUNEL assay}

To evaluate apoptosis the terminal deoxynucleotidil transferase dUTP nick and labeling (TUNEL) assay was used as previously described [25]. The apoptotic (TUNEL-positive) nuclei per field were counted in at least three fields per retinal explant using NIS-Elements imaging software (NIKON
Instruments, Badhoevedorp, The Netherlands). The number of apoptotic nuclei was normalized to the SYTOX Green-labeled cell nuclei. Results are given as percentage of apoptotic nuclei/total nuclei. Data are expressed as mean \pm SEM.

\section{Immunofluorescence of caspase-3, GFAP and PAR}

Immunofluorescence was carried out on $10-\mu$ m cryosections. Sections were post-fixed for 15 minutes at room temperature in $4 \%$ filtered paraformaldehyde (SigmaAldrich, Madrid, Spain) in 0.1 M PBS (pH 7.4). Sections were incubated for 1 hour in blocking solution containing $5 \%$ normal goat serum, $1 \%$ BSA and $0.25 \%$ Triton X-100. They were then incubated with primary antibody against cleaved caspase-3 (1:200, Cell Signaling Technology, Barcelona, Spain), glial fibrillary acidic protein (GFAP, 1:400, Sigma-Aldrich, Madrid, Spain) or PAR (1:200, Enzo Life Science, Madrid, Spain) overnight at $4^{\circ} \mathrm{C}$ in blocking solution. After this samples were incubated for one hour at room temperature with the fluorescence-conjugated secondary antibody Alexa Fluor 647 (Invitrogen, Life Technologies, Madrid, Spain) and observed under a confocal microscope (Leica TCS SP5 Confocal microscope, Leica Microsistemas SLU, Barcelona, Spain) belonging to the Microscopy Unit of the IIS-La Fe (Valencia, Spain). Cells were counted at $40 \times$ magnification, and the number of caspase-3 positive cells was counted manually in 4 fields per retinal explant. The number of cells positive for the cleaved caspase-3 immunolabeling was normalized to the SYTOX Green-labeled cell nuclei (Molecular Probes, Paisley, UK). Results are given as percentage of caspase-3 positive cell/total nuclei. Data are expressed as mean \pm SEM.

GFAP and PAR positive cells were difficult to count in different retinal layers. For the quantification we used the following formula to calculate the corrected fluorescence (CF) for each cell layer [27]:

$$
\begin{aligned}
\mathrm{CF}= & \text { Integrated density of the selected area } \\
& -(\text { area of selected area } \times \text { mean fluorescence of background })
\end{aligned}
$$

\section{Data are expressed as mean \pm SEM.}

For co-localization of cleaved caspase-3 (combined with Alexa Fluor 647) and PAR (combined with Alexa Fluor 488 (Invitrogen, Life Technologies, Madrid, Spain)) staining was followed by TUNEL staining.

\section{caspase- 3 activity assay}

caspase-3 activity was measured with a colorimetric tetrapeptide (DEVD- $p$ NA) cleavage assay kit following the manufacturer's instructions (Bio-Vision, Mountain View, CA, USA). Total retinal protein was extracted from retinal explants and measured by the bicinchoninic acid 
(BCA) protein assay. caspase-3 activity was expressed as arbitrary units $(\mathrm{au}) / \mathrm{mg}$ of protein.

\section{Nitrites and nitrates (NOX) determination}

Intracellular nitrites (stable end-product of nitric oxide $(\mathrm{NO})$ ) and nitrates (NOX) were measured in retinal explants by spectrophotometric GRIESS reaction using nitrate reductase [28]. The tissue NOX levels were expressed as $\mathrm{nmol} / \mathrm{mg}$ protein.

\section{Oxidative stress evaluation}

Retinal explants were assayed for total antioxidant capacity (TAC) and thiobarbituric acid reactive substances (TBARS) formation as indicator of malonyldialdehyde (MDA) formation.

Retinal explants were homogenized in $5 \mathrm{mM}$ phosphate buffer $\mathrm{pH} 7,0.9 \% \mathrm{NaCl}, 0.1 \%$ glucose, centrifuged at $10,000 \times g$ for 15 minutes at $4^{\circ} \mathrm{C}$, and then the supernatants were used to determine TAC and TBARS. Protein concentrations were measured by the BCA protein assay.

TAC was measured using a commercial kit (Cayman Chemical, Ann Arbor, MI, USA) [29]. The tissue TAC levels were expressed as nmol/mg protein.

MDA levels were detected by a colorimetric method involving thiobarbituric acid (TBA) adduct formation (Cayman Chemical, Ann Arbor, MI, USA). Tissue TBARS levels were expressed as nmol/mg protein.

Values for caspase-3 activity, NOX and oxidative markers are given as the mean \pm SEM of at least eight different cultures. For each experiment samples were measured in duplicate.

\section{Statistical analyses}

All statistical analyses were done using $\mathrm{R}$ software (version 2.15.3) (Foundation for Statistical Computing, Vienna, Austria). Multivariate analysis of covariance (MANCOVA) and multiple linear regression models were used to analyze human data. For parametric data, ANOVA followed by Newman-Keuls post hoc test was used. For non-parametric data, Kruskal-Wallis test followed by Dunn's Multiple Comparison test was used. Significance levels were set at $\alpha=0.05$.

\section{Results}

Increased levels of TNFa and IL- 6 in aqueous humor of RP patients

We performed a multiplex ELISA to determine the concentration of TNF $\alpha$, IL-6, IL-1 $\beta$ and IL-10 in aqueous humor of RP patients. IL-1 $\beta$ and IL-10 were below detectable levels. Descriptive statistics of the results of the measurements of IL-6 and TNF $\alpha$ are shown in Table 2. We performed a MANCOVA with the results of TNF $\alpha$ and IL-6 as dependent variables while disease, age and gender were taken as predictive variables.
Table 2 Protein levels of cytokines in aqueous humor from retinitis pigmentosa (RP) patients and healthy controls

\begin{tabular}{lll}
\hline & Control & RP \\
\hline TNF- $a(\mathrm{pg} / \mathrm{mL})$ & $1.1 \pm 0.2$ & $1.7 \pm 0.2$ \\
$95 \% \mathrm{Cl}$ & $(0.8$ to 1.4$)$ & $(1.4$ to 2.0$)$ \\
Detectable samples & $13 / 13$ & $28 / 30$ \\
$\mathrm{IL}-6(\mathrm{pg} / \mathrm{mL})$ & $10.8 \pm 3.4$ & $23.5 \pm 3.8$ \\
$95 \% \mathrm{Cl}$ & $(3.2-$ to 18.5$)$ & $(15.8$ to 31.3$)$ \\
Detectable samples & $13 / 13$ & $30 / 30$ \\
\hline
\end{tabular}

Note: values are expressed as mean $\pm \mathrm{SEM}$; $\mathrm{Cl}$ : confidence interval.

This analysis revealed that RP significantly increased inflammatory mediators IL- 6 and TNF $\alpha$ in aqueous humor $(P=0.03)$ (See Additional file 2: Table S2). We found no statistical evidence for gender or age effects. Further analysis of each of the response variables indicated that IL-6 is increased in RP patients $(P=0.018)$. TNF $\alpha$ showed a tendency to increase in RP patients $(P=0.09)$. We assessed the possible association between inflammatory status (measured as TNF $\alpha$ and IL-6 levels) and stage of the disease (measured as VF and BCVA values) using a MANOVA with VF, BCVA, sex and age as predictors and TNF $\alpha$ and IL-6 levels as response variables. Our results showed no evidence of association between VF and BCVA and inflammatory status $(P=0.09$ for VF and $P=0.94$ for visual acuity). Additionally, we also analyzed separately the associations among these predictor variables and each of the two cytokine using linear models. In these analyses we found a statistically significant association between higher VF values and higher levels of TNF $\alpha(P=0.03)$ (Figure 1).

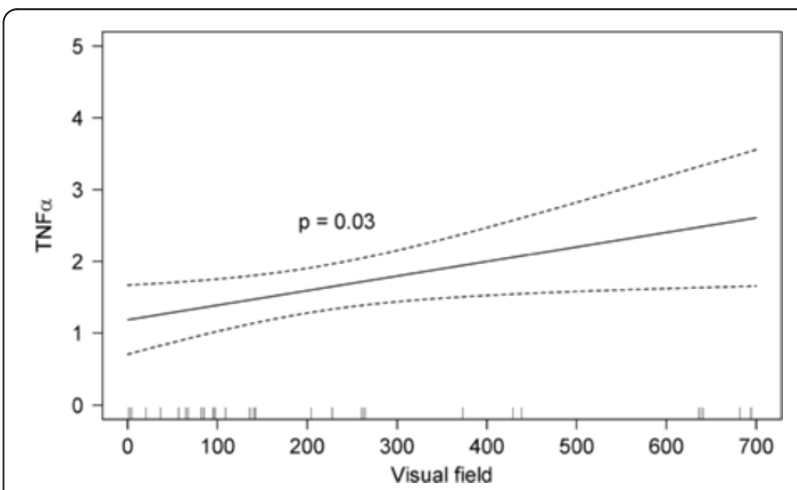

Figure 1 Relation between visual field and TNFa concentration in aqueous humor of retinitis pigmentosa (RP) patients. Statistical analysis revealed a positive relation between visual field and TNFa values controlling the other predictive variables (sex, age and acuity). Ninety-five percent confidence intervals are defined by dotted lines. 


\section{Infliximab prevents Zaprinast-induced cell death in cultured porcine retina}

We previously described that PDE6 inhibition by Zaprinast triggered retinal degeneration and induced oxidative stress and inflammatory mediators such as TNF $\alpha$ and IL-6 in cultured porcine retina after 24 hours. In particular, TNF $\alpha$ and IL-6 content increased to twice control content [25].

We tested whether incubation with $2 \mu \mathrm{g} / \mathrm{mL}$ Infliximab, a TNFo blocker, for 24 hours prevented Zaprinast-induced retinal degeneration. Firstly, we checked the effect of Infliximab on the TNFa signaling cascade. As we could not measure TNF $\alpha$, because Infliximab interferes with the ELISA assay as previously described [30], we evaluated its receptor TNF-R1 whose activation is involved in multiple apoptotic pathways. TNF-R1 relative expression increased up to $1.36 \pm 0.08$ arbitrary units (ANOVA Newman-Keuls post-test, $P<0.0001)$ in Zaprinast-treated explants compared to control explants $(1.00 \pm 0.08$ arbitrary units). However, Infliximab normalized Zaprinast-induced overexpression of TNF-R1 (0.90 \pm 0.08 arbitrary units,
ANOVA Newman-Keuls post-test, $P<0.0001)$. No significant changes were found in explants treated only with Infliximab (0.91 \pm 0.06 arbitrary units).

As shown in Figure 2, Infliximab significantly reduced the number of TUNEL-positive cells in Zaprinast-treated explants from $7.0 \pm 0.7 \%$ to $2.2 \pm 0.3 \%$ (Kruskal-Wallis, Dunn's post-test, $P<0.001$ ) (Figure $2 \mathrm{~A}$ ). As shown in Table 3, this reduction occurred mainly in the outer nuclear layer (ONL).

As mentioned above, TNF $\alpha$ can trigger programmed cell death by activating the extrinsic and intrinsic apoptotic pathways that converges on the execution pathway, which is initiated by the cleavage of caspase-3 [31]. The activity of caspase- 3 in Zaprinast-treated explants was $2.3 \pm 0.2 \mathrm{au} / \mathrm{mg}$ protein (ANOVA Newman-Keuls post-test, $P<0.01$ ) and $1.3 \pm 0.2 \mathrm{au} / \mathrm{mg}$ protein in control explants. Infliximab almost normalized caspase- 3 activity $(1.7 \pm 0.2 \mathrm{au} / \mathrm{mg}$ protein) compared to Zaprinast-treated explants (ANOVA Newman-Keuls post-test, $P<0.05)$ and the percentage of cleaved caspase- 3 positive cells $(1.1 \pm 0.3 \%)$ compared

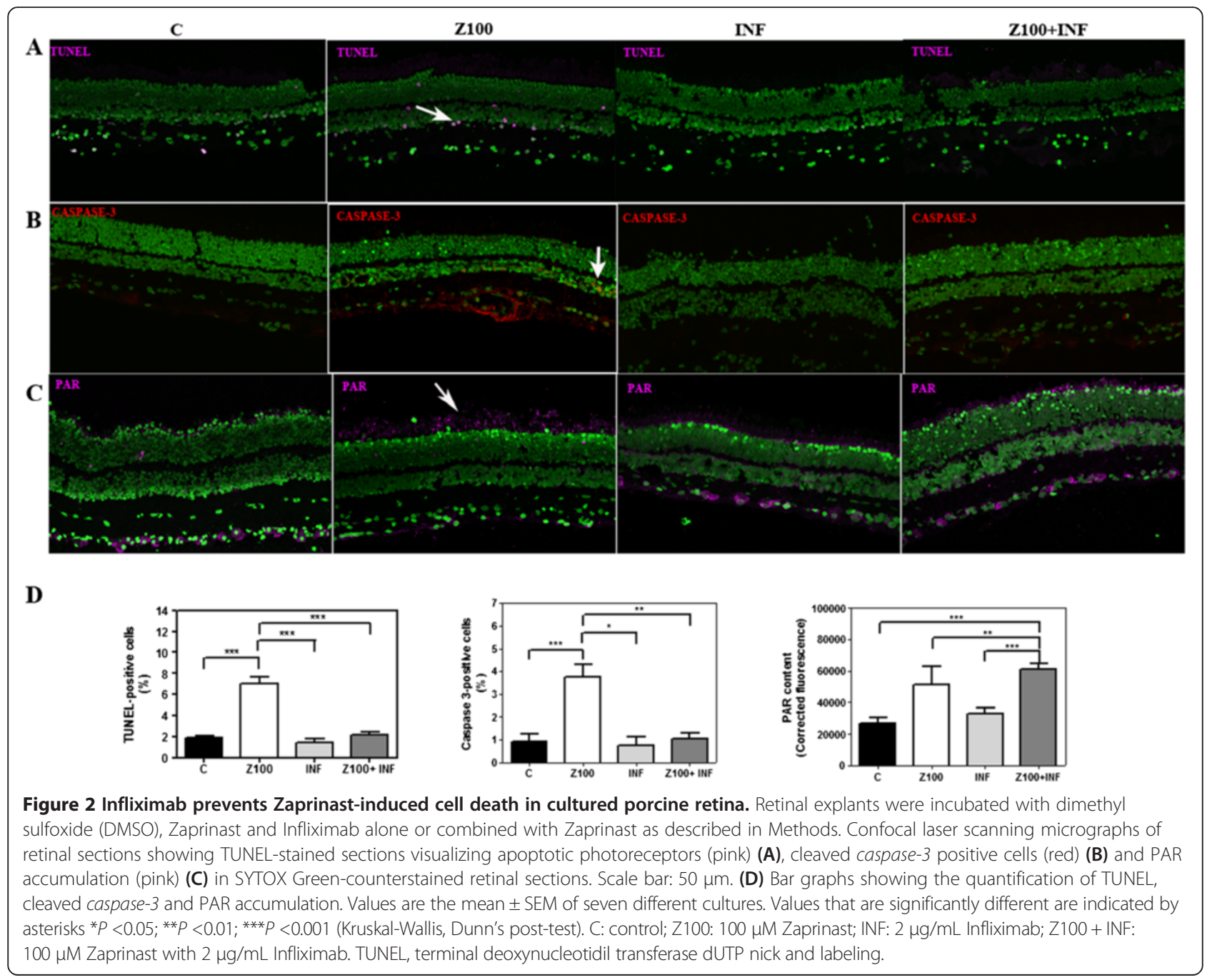


Table 3 Effect of Infliximab treatment on cell death markers in Zaprinast-treated retinal explants TUNEL-positive cells (\%)

\begin{tabular}{|c|c|c|c|c|c|c|c|c|c|c|c|c|}
\hline \multirow[b]{2}{*}{ Layer } & \multicolumn{4}{|c|}{ TUNEL-positive cells (\%) } & \multicolumn{4}{|c|}{ caspase-3 positive cells (\%) } & \multicolumn{4}{|c|}{ PAR content (CF) } \\
\hline & C & $\mathrm{Z} 100$ & INF & $\mathrm{Z} 100+\mathrm{INF}$ & C & $\mathrm{Z} 100$ & INF & $\mathrm{Z} 100+\mathrm{INF}$ & C & $\mathrm{Z} 100$ & INF & $\mathrm{Z} 100+\mathrm{INF}$ \\
\hline$\overline{\mathrm{ONL}}$ & $0.3 \pm 0.1$ & $3.0 \pm 1.1^{a}$ & $0.4 \pm 0.2^{b}$ & $0.2 \pm 0.1^{c}$ & $0.07 \pm 0.04$ & $0.2 \pm 0.1$ & $0.01 \pm 0.01^{b}$ & $0.04 \pm 0.03^{c}$ & $7,647 \pm 676$ & $22,925 \pm 5111^{a}$ & $15,982 \pm 2,019$ & $24,970 \pm 1,807^{d, e}$ \\
\hline INL & $1.1 \pm 0.2$ & $2.5 \pm 0.4^{a}$ & $0.8 \pm 0.3^{b}$ & $1.1 \pm 0.3$ & $0.2 \pm 0.1$ & $2.1 \pm 0.3^{\mathrm{a}}$ & $0.4 \pm 0.3^{b}$ & $0.4 \pm 0.1^{c}$ & $7,019 \pm 1,163$ & $9,348 \pm 2,288$ & $11,156 \pm 1,879$ & $21,511 \pm 2,251^{c, d, e}$ \\
\hline $\mathrm{GCL}$ & $0.7 \pm 0.1$ & $2.0 \pm 0.4^{a}$ & $0.6 \pm 0.3^{b}$ & $1.0 \pm 0.3$ & $0.6 \pm 0.3$ & $1.3 \pm 0.2^{\mathrm{a}}$ & $0.3 \pm 0.1$ & $0.6 \pm 0.2^{c}$ & $9,891 \pm 2,011$ & $10,019 \pm 2,212$ & $10,204 \pm 1,496$ & $17,134 \pm 2,274^{c, e}$ \\
\hline
\end{tabular}

Note: Kruskal-Wallis test and Dunn's Multiple Comparisons were used. Values different from control are shown by ${ }^{\mathrm{a}}(P<0.05)$. Superscripts represent statistical differences $(P<0.05)$ between ${ }^{\mathrm{b} Z 100}$ and INF; ${ }^{\mathrm{C} Z 100}$ and $\mathrm{Z} 100+\mathrm{INF} ;{ }^{\mathrm{d} I N F}$ and Z100 + INF; ${ }^{\circ} \mathrm{C}$ and Z100 + INF respectively. ONL: outer nuclear layer; INL: inner nuclear layer; GCL: ganglion nuclear layer; PAR, poly(ADP-ribose) polymers; C: control; Z100: 100 $\mu \mathrm{M}$ Zaprinast; INF; $2 \mu \mathrm{g} / \mathrm{mL}$ Infliximab; Z100 + INF: $100 \mu \mathrm{M}$ Zaprinast with $2 \mu \mathrm{g} / \mathrm{mL}$ Infliximab; CF: corrected fluorescence. 
to Zaprinast-treated explants $(3.8 \pm 0.6 \%$, Kruskal-Wallis, Dunn's post-test, $P<0.01)$. Moreover, immunostaining of cleaved caspase-3 revealed that Infliximab treatment reduced the percentage of caspase- 3 positive cells at all cell layers (outer, inner and ganglion layer (ONL, INL and GCL)) (Kruskal-Wallis, Dunn's post-test, $P<0.05$ ) (Table 3 and Figure 2B).

We have previously observed an over activation of poly(ADP-ribose) polymerase (PARP) in our model of porcine retinal degeneration [25]. Moreover, other authors have described similar results in other animal models of retinal degeneration [32,33]. Therefore, we investigated whether TNF $\alpha$ mediated cell death via the PARP pathway. Accumulation of poly(ADP-ribose) polymers (PAR) was used to analyze indirectly PARP activity indirectly. Immunostaining of PAR revealed a significant accumulation of these polymers in ONL and outer segments (OS) in Zaprinast-treated explants (Kruskal-Wallis, Dunn's post-test, $P<0.05)$ that were not prevented by Infliximab treatment (Table 3 and Figure 2C). Infliximab treatment increased PAR accumulation at all cell layers of Zaprinast-treated explants. Thus, the inhibition of TNF $\alpha$ by Infliximab is not causally linked to PARP activation, and therefore does not prevent the secondary PAR accumulation.

To determine whether cleaved caspase-3 or PAR accumulation co-localize with TUNEL-positive cells, we performed triple labeling (Figure 3). In Zaprinast-treated explants PAR immunostaining co-localized with TUNELpositive cells in some cells of ONL, in a few cells of the INL and in several cells of GCL. This co-localization disappeared after Infliximab treatment in ONL and GCL but remained in a subset of cells of the INL. PAR accumulation remained high, and even increased, at all cell layers, although the number of TUNEL-positive cells decreased.

However, caspase-3 positive cells did not co-localize with TUNEL-positive cells except for a subset of cells in INL in Zaprinast-treated explants. Co-localization of caspase-3 with TUNEL-positive cells disappeared after Infliximab treatment but increased co-localization of caspase-3 with PAR in INL.

\section{Infliximab ameliorates Zaprinast-induced glial activation in cultured porcine retina}

Gliosis commonly involves upregulation of the intermediate filament protein, GFAP, in Müller glial cells. We studied whether Zaprinast-induced retinal degeneration was accompanied by altered glial reactivity, and if it was the case, whether the blockade of TNF $\alpha$ could prevent it.

In control explants, GFAP were located in the inner half of the retinal Müller cells and their endfeet (GCL layer). However, Zaprinast-treated explants exhibited strong GFAP-positive staining of Müller cells. After PDE6 inhibition, GFAP was massively upregulated throughout the retinal explant. After Infliximab treatment the GFAP-positive labeling was significantly decreased (Figure 4).

\section{Infliximab partially prevents Zaprinast-induced oxidative stress in cultured porcine retina}

cGMP accumulation induces oxidative stress in murine models of retinal degeneration [34] as it does in our model of porcine retina treated with Zaprinast [25]. To explore whether Infliximab also prevented Zaprinast-induced oxidative damage in cultured porcine retina, we measured intracellular nitrite formation (iNOX), as stable NO metabolite, TBARS content as indicator of MDA and total antioxidant capacity (TAC).

As shown in Figure 5, Infliximab normalized TAC but did not prevent oxidative stress in Zaprinast-treated explants. Total antioxidant capacity returned to control level $(230 \pm 15 \mu \mathrm{mol} / \mathrm{mg}$ protein, ANOVA Newman-Keuls post-test, $P<0.05$ ) (Figure $5 \mathrm{~A}$ ), but TBARS formation (Figure 5B) and intracellular NOX (Figure 5C) remained high after the blockade of TNF $\alpha$.

\section{Discussion}

Abnormal pathological pathways such as oxidative stress and inflammation, including upregulation of TNF $\alpha$, have been described in retinal neurodegenerative diseases both affecting the outer retina, such as RP and age-related macular degeneration (AMD), and the inner retina, such as glaucoma and ischemic retinopathy [35-39]. Low-grade inflammation is present in AMD and glaucoma. For instance, in AMD, many mediators of chronic low-grade inflammation such as $\mathrm{C}$-reactive protein, immunoglobulins, and acute phase molecules, the complement-related proteins, autoantibodies, macrophage infiltration and microglial activation have been found [40]. In glaucoma, microglial activation and an inflammatory response involving Toll-like receptors (TLRs), complement molecules and cytokines, such as TNF $\alpha$ and IL-1 $\beta$, is associated with secondary phase of the disease [41]. Much less is known about the inflammatory response to retinal ischemic-reperfusion (IR) injury. However, pro-inflammatory gene upregulation, accumulation of leukocytes, and microglial activation is found following IR in rodent retinas [42].

In $\mathrm{RP}$, retinal degeneration is caused by various mutations that result in rod death followed by gradual death of cones [43]. Growing evidence suggests that, regardless of the causative mutation, neuroinflammation contributes to photoreceptor degeneration [44,45]. For instance, different animal models of RP ( $r d s$ mice, $r d 1$ mice, P23 rats, RCS rats) carrying mutations in different genes (Prph2, PDE6, Rho, Mertk) show signals of an inflammatory process [23,46-49]. In early stages of retinal degeneration the photoreceptor cells and surrounding cells, such as microglia, respond to unfavourable conditions with the production of 


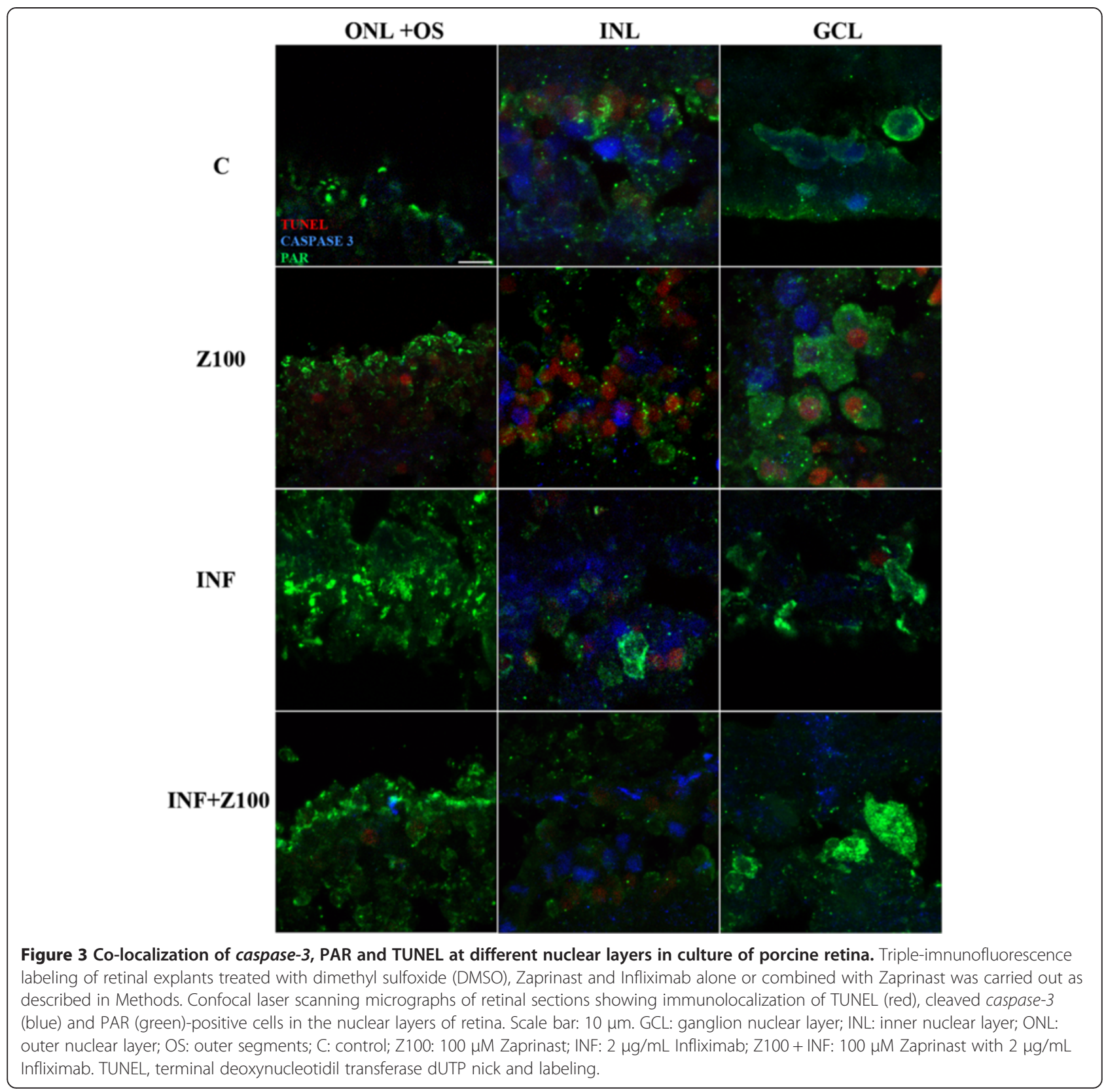

cytokines, chemokines, growth factors, and so on, in an attempt to protect neurons and to preserve retinal function. As disease progresses, sustained inflammatory mediators and others such as oxidative stress may exacerbate photoreceptor cell death and RP progression.

Early studies suggested the presence of immune reactivity in RP patients, including the presence of retinal autoantibodies in blood and lymphocytes in vitreous humor. However, these results were variable, maybe due to the inherent genetic heterogeneity of this disease [36]. Afterwards, microglial activation, a common hallmark of both inherited and induced retinal degeneration, was described in RP patients and murine models of RP $[12,45,50-53]$. It has been shown that microglial activation leads to proliferation, followed by migration to damaged sites and release of cytokines (TNF $\alpha$, IL- $1 \alpha$, IL-1 $\beta$ ) chemokines, neurotrophins, glutamate, NO, superoxide anions and prostaglandins to repair tissue damage. Although these events are triggered to prevent cell damage, sustained high levels of these molecules, especially cytokines, can cause progressive neurodegeneration. In models of RP, microglial activation coincides, or precedes, the peak of photoreceptor cell death and with high levels of TNF $\alpha[12,44,45,50,54,55]$ that seems to be 

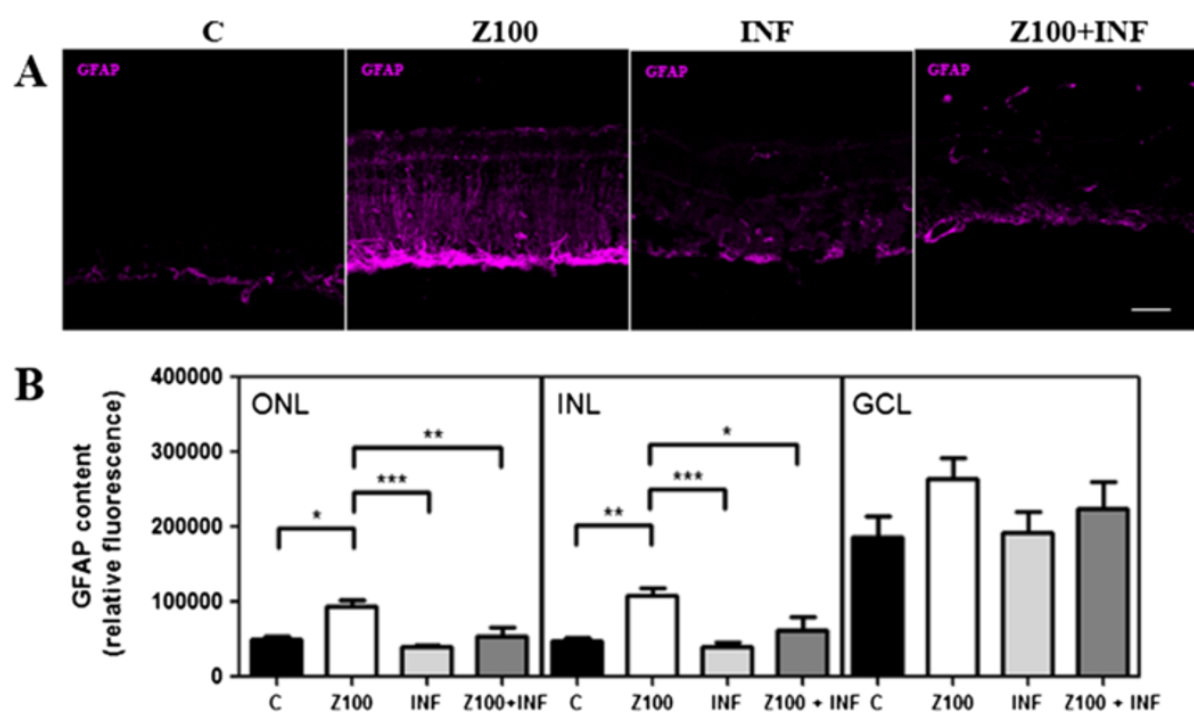

Figure 4 Infliximab prevents Zaprinast-induced glial fibrillary acidic protein (GFAP) overexpression in cultured porcine retina. Retinal explants were incubated with dimethyl sulfoxide (DMSO), Zaprinast and Infliximab alone or combined with Zaprinast as described in Methods. (A) Confocal laser scanning micrographs of retinal sections showing GFAP content. Scale bar: $50 \mu \mathrm{m}$. (B) Bar graphs showing the quantification of GFAP content. Values are the mean \pm SEM of six different cultures. Values that are significantly different are indicated by asterisks $* P<0.05$, ${ }^{* *} P<0.01,{ }^{* *} P<0.001$ (Kruskal-Wallis, Dunn's post-test). C: control; Z100: $100 \mu \mathrm{M}$ Zaprinast; INF: $2 \mu \mathrm{g} / \mathrm{mL}$ Infliximab; Z100 +INF: $100 \mu M$ Zaprinast with $2 \mu \mathrm{g} / \mathrm{mL}$ Infliximab.

toxic for photoreceptor cells in vitro [23]. Besides, microglial inhibition reduces photoreceptor cell death, TNF $\alpha$ content and improves visual function [46].

In our human study we confirmed (1) the presence of high levels of TNF $\alpha$ and IL-6 in aqueous humor in a larger population of RP patients than previously reported [11]; and we observed that (2) RP patients with higher TNFo values show better visual function (visual field). The conflictive positive correlation, between TNF $\alpha$ and better visual function, may be due to the different stage of the disease of the patients. It has been shown that an increase of proinflammatory markers, including TNF $\alpha$, in mice models of RP occurs just before photoreceptor cell loss [12]. Therefore, it is tempting to speculate that at early onset of RP, when proinflammatory markers are elevated, visual function is better in patients, and after these stages patients lose visual function in parallel with TNF $\alpha$ decrease. In any case, these conflicting, and interesting, results strongly suggest that further studies are needed for clarification.

In the last few years, TNF $\alpha$ has been widely recognized as an attractive therapeutic target for the treatment of retinal diseases. Different types of monoclonal antibodies against TNFa, such as Infliximab, Adalimumab, Certolizumab pegol and Golimumab, or circulating receptor fusion protein, such as Etanercept, have been used to treat glaucoma [56,57], ischemic retinopathy [58] or AMD [59].

The role of TNF $\alpha$ in photoreceptor degeneration and the possible therapeutic use of antibodies against TNF $\alpha$ in the treatment of RP or other retinal degenerations remain quite unexplored. Based on previous studies we decided to evaluate the potential protective effect of the blockade of TNF $\alpha$ in an experimental porcine model of retinal degeneration. In a previous report we demonstrated that this porcine model recapitulated some aspects, especially those related to oxidative stress and inflammation, of the retinal degeneration observed in small animals after PDE inhibition [60,61] and RP patients $[8,11]$. Sustained elevation of intracellular cGMP in porcine retinal explants triggered different downstream effectors of cell death related to caspase-dependent mechanisms (caspase-3) and caspase-independent mechanisms (calpain-2 and probably PARP activity) [25].

Our current study demonstrated that retinal degeneration accompanied by upregulation of TNF $\alpha$ and IL-6, GFAP and oxidative damage was ameliorated by blocking TNF $\alpha$ with Infliximab. Under our experimental conditions, Infliximab reduced retinal degeneration in all cell layers, mainly in the ONL, by decreasing the number of TUNEL-positive cells, supporting the idea that inflammation plays an important role in the processes of cell death.

We found that Infliximab reduced caspase-3 activity and the number of cleaved caspase- 3 positive cells across the different cell layers, especially at the INL. Co-localization studies of caspase-3 and PAR with TUNEL assay suggested that TNF $\alpha$ is promoting cell death through caspase-independent mechanisms in ONL and GCL and caspase-dependent mechanisms in INL. 

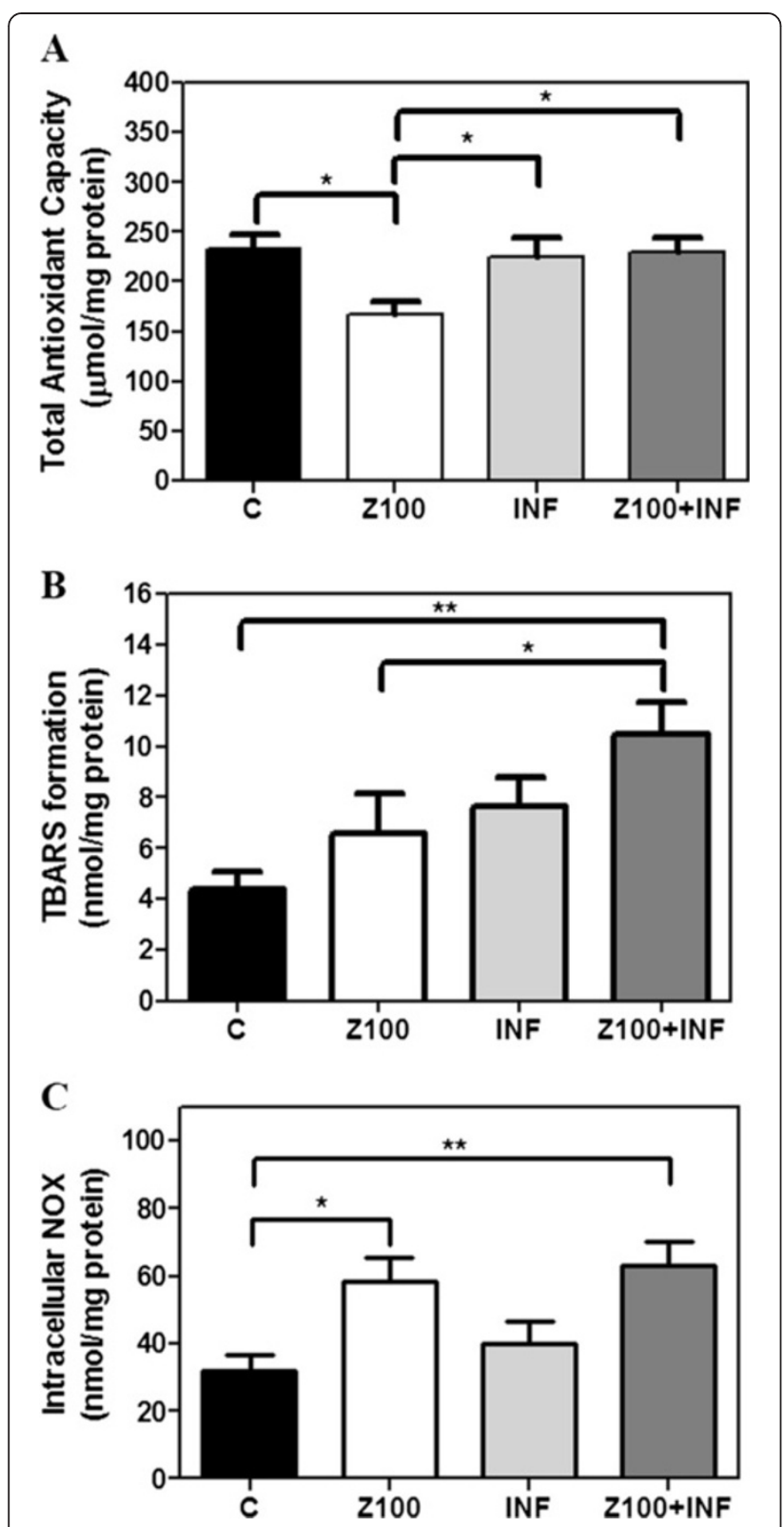

Figure 5 Infliximab partially prevents Zaprinast-induced oxidative stress in cultures of porcine retina. Retinal explants were incubated with dimethyl sulfoxide (DMSO), Zaprinast and Infliximab alone or combined with Zaprinast as described in Methods. Effect of Infliximab on the total antioxidant capacity (A), TBARS formation (B) and intracellular NOX (C). Each sample was measured in duplicate, and the values are the mean \pm SEM of eight cultures. ANOVA Newman-Keuls post-test was used for TAC analysis. Kruskal-Wallis test and Dunn's post-test was used for TBARS and iNOX analysis. ${ }^{*} P<0.05,{ }^{* *} P<0.01$. C: control; Z100: $100 \mu \mathrm{M}$ Zaprinast; INF: $2 \mu \mathrm{g} / \mathrm{mL}$ Infliximab; Z100 +INF: $100 \mu \mathrm{M}$ Zaprinast with $2 \mu \mathrm{g} / \mathrm{mL}$ Infliximab. iNOX, intracellular nitrites and nitrates; TAC, total antioxidant capacity; TBARS, thiobarbituric acid reactive substances.

TNF signaling can lead to cell death to two distinct outcomes, each of which is initiated by different signaling complexes: the apoptosis mode and the necrosis mode.
The apoptosis mode includes the extrinsic pathway, mainly mediated by caspases, and the intrinsic or mitochondrial pathway, that rely on the balance between the proapoptotic and the anti-apoptotic proteins from the Bcl-2 family. Both pathways converge on the same execution pathway. The execution pathway is initiated by the cleavage of caspase-3 and results in DNA fragmentation and cell death.

We measured indirect activation of PARP through quantification of PAR accumulation. We found an upregulation of PAR due to PDE6 inhibition. However, blockade of TNF $\alpha$ did not prevent PAR accumulation but also increased it. PAR polymers are mainly degraded by poly (ADP-ribose) glycohydrolase (PARG) enzymes, some of them activated by caspase- 3 cleavage [62]. On the other hand, PARP can be inactivated by caspase-3 cleavage [63]. Therefore, the inhibition of caspase-3 induced by Infliximab could inhibit PARG activity and prevent PARP inactivation thus exacerbating PAR accumulation at all cell layers of retinal explants. These results support that PARP pathway is independent of TNF $\alpha$-associated pathways in this experimental model of retinal degeneration (Figure 6).

These results were supported by previous reports in which reactive gliosis (GFAP overexpression) induced by exogenous TNF $\alpha$ was prevented by Adalimumab, other monoclonal anti-TNF $\alpha$, in a similar model of organotypic culture of porcine neuroretina [64]. Activated Müller cells can release antioxidants, growth factors, and cytokines, including TNF $\alpha$, contributing to retinal regeneration or to neurodegeneration. Müller cells are activated in models of RP [49,65-68] resulting in overexpression of GFAP, translocation of Müller cell bodies to the outer retina and thickening of their processes [69].

As previously shown, retinal degeneration induced by PDE inhibition was accompanied by oxidative stress in porcine retinas [25]. This is consistent with the idea that oxidative stress is also contributing to the progression of $\mathrm{RP}$ in animal models [70-72] and RP patients [8]. In the current study, we demonstrated that Infliximab partially prevented antioxidant defense depletion but not oxidative stress markers. Infliximab normalized the total antioxidant capacity in Zaprinast-treated explants, but it failed to return TBARS and NOX to control levels. In retinas of rd10 mice antioxidant treatment reduced inflammatory mediators and photoreceptor cell loss [12]. Based on these data, it is tempting to speculate that the low Infliximab effect could be due to oxidative stress preceding upregulation of inflammatory mediators [12,73-75]. The other possibility is that Infliximab affects other oxidative stress markers that we did not measure in this study. Anyway, further studies will be needed to explore this issue in more depth.

In summary, our results corroborate that RP patients have ocular inflammation and that TNF $\alpha$ plays an important role 


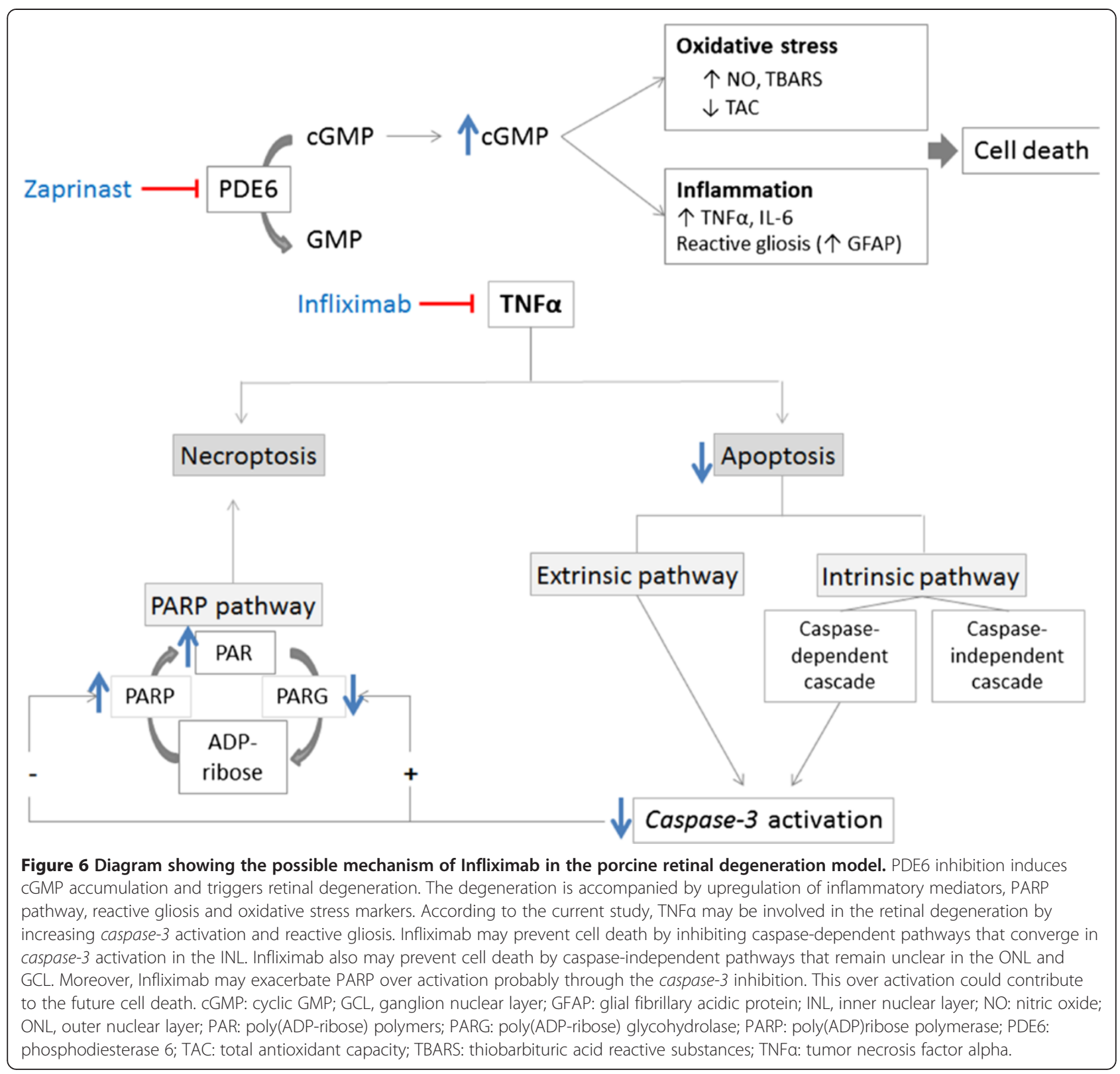

in the retinal degeneration induced by PDE6 inhibition in cultured porcine retinas. The mechanisms of cell death vary in the distinct cell layers. TNF $\alpha$ is involved in retinal degeneration through caspase-3 activation, caspase-independent mechanisms and reactive gliosis. Our data suggest that other unknown molecules must be contributing to TNF $\alpha$ mediated cell death in this model. On the other hand, PARP activation is independent of TNF $\alpha$ signaling and it is probably responsible for a future cell death in ONL. The existence of several distinct pathways that trigger programmed cell death implies that an efficient protection requires their simultaneous interruption via combined therapies.

The experimental model of organotypic culture has its own limitations because it involves transection of the optic nerve and mechanical retinal detachment causing retrograde retinal ganglion cell degeneration. To minimize this problem, we have used detached retinas as controls. Moreover, the model cannot recapitulate the whole chronic nature of the degeneration, but we believe that it could be useful for studying some aspects related to the retinal degeneration. In our case, we believe that it may provide a helpful model to design and assay some treatments, such as Infliximab, thus replacing or reducing animal experiments. The use of this model allowed us to evaluate the effect of Infliximab faster and more cheaply than using the available in vivo models of RP.

The current model of retinal degeneration allowed us to describe an interesting and, in our opinion, neuroprotective 
effect of Infliximab that strongly encourages further exploration using other experimental models. Due to the importance of the inflammatory process in the pathogenesis of several retinal degenerative conditions such as RP, AMD, ischemic retinopathy, or glaucoma, targeting inflammation could be a promising therapeutic strategy. In particular, TNF $\alpha$ blockers could be a new therapeutic strategy for the treatment of RP and other retinal degenerative conditions.

\section{Additional files}

Additional file 1: Table S1. Individual data for each patient with retinitis pigmentosa (RP).

Additional file 2: Table S2. MANCOVA in aqueous humor from retinitis pigmentosa (RP) patients and healthy controls.

\section{Abbreviations}

AIF: apoptosis inducing factor; AMD: age related macular degeneration; ANCOVA: analysis of variance; au: arbitrary units; BCVA: best-corrected visual acuity; BCA: bicinchoninic acid; BSA: bovine serum albumin; cGMP: cyclic guanosine monophosphate; DMSO: dimethyl sulfoxide; ELISA: enzyme-linked immunosorbent assay; GCL: ganglion nuclear layer; GFAP: glial fibrillary acidic protein; IL: interleukin; INL: inner nuclear layer; iNOX: intracellular nitrite; IR: ischemic-reperfusion; MANCOVA: multivariate analysis of covariance; MDA: malonyldialdehyde; NO: nitric oxide; NOX: intracellular nitrates and nitrites; ONL: outer nuclear layer; PAR: poly(ADP-ribose); PARP: poly(ADPribose) polymerase; PBS: phosphate-buffered saline; PDE6: phosphodiesterase 6; RP: retinitis pigmentosa; TAC: total antioxidant capacity; TBA: thiobarbituric acid; TBARS: thiobarbituric acid reactive substances; TLRs: Toll-like receptors; TNFa: tumor necrosis factor alpha; TUNEL: terminal deoxynucleotidil transferase dUTP nick and labeling; VF: visual field.

\section{Competing interests}

The authors declare that no competing financial or non-financial interests exist.

\section{Authors' contributions}

CMFC carried out biochemical determinations, performed histological analysis and helped to write the draft. LOG carried out organotypic cell cultures and helped to biochemical and histological analysis. DH carried out statistical analysis and helped to revise the draft. DS obtained human samples and carried out ophthalmic examination. JMM participated in the design of the study and helped to revise the manuscript. RR conceived the study, designed and coordinated the study, performed cytokine determinations in human samples, analyzed data and wrote the draft. All authors read and approved the final manuscript.

\section{Acknowledgements}

We are very grateful to the patients participating in the current study and to their relatives, to ONCE and to RETINA COMUNIDAD VALENCIANA. We thank Juan Martín (Local Slaughterhouse MercaValencia, Valencia, Spain) for providing pig eyes and the Microscopy Unit of IIS-La Fe. This work was supported by the European Regional Development Fund, Institute of Health Carlos III, PI10/01825 and PI12/0481 from the Spanish Ministry of Economy and Competitiveness (MEC). CIBERER is an initiative of the Institute of Health Carlos III from the MEC. Regina Rodrigo has a research-contract SNS Miguel Servet (CP09/118) from Institute of Health Carlos III.

\section{Author details}

'Sensorineural Disorders, Health Research Institute-La Fe, Valencia, Spain. ${ }^{2}$ Biostatistics Unit, Health Research Institute-La Fe, Valencia, Spain.

${ }^{3}$ Department of Ophthalmology, La Fe University Hospital, Valencia, Spain. ${ }^{4}$ Centre for Biomedical Network Research on Rare Diseases (CIBERER), Madrid, Spain. ${ }^{5}$ Genetics Unit, La Fe University Hospital, Valencia, Spain. ${ }^{6}$ Laboratory of Molecular, Cellular and Genomic Biomedicine, Institute of Health ResearchLa Fe, Avenida Fernando Abril Martorell 106, 46026 Valencia, Spain.
Received: 7 June 2014 Accepted: 25 September 2014

Published online: 10 October 2014

\section{References}

1. Kalloniatis M, Fletcher EL: Retinitis pigmentosa: understanding the clinical presentation, mechanisms and treatment options. Clin Exp Optom 2004, 87:65-80.

2. Corton M, Blanco MJ, Torres M, Sánchez-Salorio M, Carracedo A, Brion M: Identification of a novel mutation in the human PDE6A gene in autosomal recessive retinitis pigmentosa: homology with the nmf28/nmf28 mice model. Clin Genet 2010, 78:495-498.

3. Dryja TP, Rucinski DE, Chen SH, Berson EL: Frequency of mutations in the gene encoding the alpha subunit of rod cGMP-phosphodiesterase in autosomal recessive retinitis pigmentosa. Invest Ophthalmol Vis Sci 1999, 40:1859-1865.

4. Huang SH, Pittler SJ, Huang X, Oliveira L, Berson EL, Dryja TP: Autosomal recessive retinitis pigmentosa caused by mutations in the alpha subunit of rod cGMP phosphodiesterase. Nat Genet 1995, 11:468-471.

5. McLaughlin ME, Ehrhart TL, Berson EL, Dryja TP: Mutation spectrum of the gene encoding the beta subunit of rod phosphodiesterase among patients with autosomal recessive retinitis pigmentosa. Proc Natl Acad Sci US A 1995, 92:3249-3253.

6. Ayuso C, Millan JM: Retinitis pigmentosa and allied conditions today: a paradigm of translational research. Genome Med 2010, 2:34.

7. Retinal Information Network. In [http://www.sph.uth.tmc.edu/RetNet]

8. Martínez-Fernández dela Cámara C, Salom D, Sequedo MD, Hervás D, Marín-Lambíes C, Aller E, Jaijo T, Díaz-Llopis M, Millán JM, Rodrigo R: Altered antioxidant-oxidant status in the aqueous humor and peripheral blood of patients with retinitis pigmentosa. PLoS One 2013, 8:e74223.

9. Uliss AE, Gregor ZJ, Bird AC: Retinitis pigmentosa and retinal neovascularization. Ophthalmology 1986, 93:1599-1603.

10. Newsome DA, Anderson RE, May JG, McKay TA, Maude M: Clinical and serum lipid findings in a large family with autosomal dominant retinitis pigmentosa. Ophthalmology 1988, 95:1691-1695.

11. Yoshida N, Ikeda Y, Notomi S, Ishikawa K, Murakami Y, Hisatomi T, Enaida H, Ishibashi T: Clinical evidence of sustained chronic inflammatory reaction in retinitis pigmentosa. Ophthalmology 2013, 120(1):100-105.

12. Yoshida N, Ikeda Y, Notomi S, Ishikawa K, Murakami Y, Hisatomi T, Enaida H, Ishibashi T: Laboratory evidence of sustained chronic inflammatory reaction in retinitis pigmentosa. Ophthalmology 2013, 120(1):e5-e12.

13. Vandenabeele $P$, Declercq W, Beyaert R, Fiers W: Two tumour necrosis factor receptors: structure and function. Trends Cell Biol 1995, 5:392-399.

14. Durrani K, Ahmed M, Foster CS: Adamantiades-Behcet disease: diagnosis and current concepts in management of ocular manifestations. Compr Ophthalmol Update 2007, 8:225-233.

15. Japiassu RM, Brasil OF, Cunha AL, de Souza EC: Regression of vasoproliferative tumor with systemic infliximab. Ophthalmic Surg Lasers Imaging 2008, 39:348-349.

16. Seddon JM, George S, Rosner B, Rifai N: Progression of age-related macular degeneration: prospective assessment of $\mathrm{C}$-reactive protein, interleukin 6, and other cardiovascular biomarkers. Arch Ophthalmol 2005, 123:774-782.

17. Murray PI, Hoekzema R, Van Haren MA, De Hon FD, Kijlstra A: Aqueous humor interleukin-6 levels in uveitis. Invest Ophthalmol Vis Sci 1990, 31:917-920.

18. Cvenkel B, Kopitar AN, Ihan A: Inflammatory molecules in aqueous humour and on ocular surface and glaucoma surgery outcome. Mediators Inflamm 2010, 2010:939602.

19. Saxena S, Khanna VK, Pant AB, Meyer $\mathrm{CH}$, Singh VK: Elevated tumor necrosis factor in serum is associated with increased retinal ischemia in proliferative Eales' disease. Pathobiology 2011, 78:261-265.

20. Maianski NA, Roos D, Kuijpers TW: Tumor necrosis factor alpha induces a caspase-independent death pathway in human neutrophils. Blood 2003 101:1987-1995.

21. Nagata S: Apoptosis by death factor. Cell 1997, 88:355-365

22. Sosna J, Voigt S, Mathieu S, Lange A, Thon L, Davarnia P, Herdegen T, Linkermann A, Rittger A, Chan FK, Kabelitz D, Schutze S, Adam D: TNF-induced necroptosis and PARP-1-mediated necrosis represent distinct routes to programmed necrotic cell death. Cell Mol Life Sci 2014, 71:331-348. 
23. De Kozak Y, Cotinet A, Goureau O, Hicks D, Thillaye-Goldenberg B: Tumor necrosis factor and nitric oxide production by resident retinal glial cells from rats presenting hereditary retinal degeneration. Ocul Immunol Inflamm 1997, 5:85-94.

24. Yang LP, Zhu XA, Tso MO: A possible mechanism of microglia-photoreceptor crosstalk. Mol Vis 2007, 13:2048-2057.

25. Martínez-FernándezdelaCámara C, Sequedo MD, Gomez-Pinedo U, Jaijo T, Aller E, García-Tárraga P, García-Verdugo JM, Millán JM, Rodrigo R: Phosphodiesterase inhibition induces retinal degeneration, oxidative stress and inflammation in cone-enriched cultures of porcine retina. Exp Eye Res 2013, 111C:122-133.

26. Zhang $X$, Feng Q, Cote RH: Efficacy and selectivity of phosphodiesterase-targeted drugs in inhibiting photoreceptor phosphodiesterase (PDE6) in retinal photoreceptors. Invest Ophthalmol Vis Sci 2005, 46:3060-3066.

27. Burgess A, Vigneron S, Brioudes E, Labbe JC, Lorca T, Castro A: Loss of human Greatwall results in $\mathrm{G} 2$ arrest and multiple mitotic defects due to deregulation of the cyclin B-Cdc2/PP2A balance. Proc Natl Acad Sci U S A 2010, 107:12564-12569.

28. El-Mlili N, Rodrigo R, Naghizadeh B, Cauli O, Felipo V: Chronic hyperammonemia reduces the activity of neuronal nitric oxide synthase in cerebellum by altering its localization and increasing its phosphorylation by calcium-calmodulin kinase II. J Neurochem 2008, 106:1440-1449.

29. Kowluru RA, Kowluru V, Xiong Y, Ho YS: Overexpression of mitochondrial superoxide dismutase in mice protects the retina from diabetes-induced oxidative stress. Free Radic Biol Med 2006, 41:1191-1196.

30. Schulz M, Dotzlaw H, Neeck G: Ankylosing spondylitis and rheumatoid arthritis: serum levels of TNF-alpha and Its soluble receptors during the course of therapy with etanercept and infliximab. Biomed Res Int 2014, 2014:675108.

31. Berridge MJ: Cell Stress, Inflammatory Responses and Cell Death. In Cell Signalling Biology; 2012. doi:10.1042/csb0001011.

32. Paquet-Durand F, Silva J, Talukdar T, Johnson LE, Azadi S, Van Veen T, Ueffing M, Hauck SM, Ekstrom PA: Excessive activation of poly(ADP-ribose) polymerase contributes to inherited photoreceptor degeneration in the retinal degeneration 1 mouse. J Neurosci 2007, 27:10311-10319.

33. Kaur J, Mencl S, Sahaboglu A, Farinelli P, Van Veen T, Zrenner E, Ekstrom $P$, Paquet-Durand F, Arango-González B: Calpain and PARP activation during photoreceptor cell death in $\mathrm{P} 23 \mathrm{H}$ and S334ter rhodopsin mutant rats. PLoS One 2011, 6:e22181.

34. Sharma AK, Rohrer B: Sustained elevation of intracellular cGMP causes oxidative stress triggering calpain-mediated apoptosis in photoreceptor degeneration. Curr Eye Res 2007, 32:259-269.

35. Al-Gayyar MM, Elsherbiny NM: Contribution of TNF-alpha to the development of retinal neurodegenerative disorders. Eur Cytokine Netw 2013, 24:27-36.

36. Viringipurampeer IA, Bashar AE, Gregory-Evans CY, Moritz OL, Gregory-Evans K Targeting inflammation in emerging therapies for genetic retinal disease. Int J Inflam 2013, 2013:581751.

37. Kandarakis SA, Piperi C, Topouzis F, Papavassiliou AG: Emerging role of advanced glycation-end products (AGEs) in the pathobiology of eye diseases. Prog Retin Eye Res 2014, 42C:85-102.

38. Tarr JM, Kaul K, Chopra M, Kohner EM, Chibber R: Pathophysiology of diabetic retinopathy. ISRN Ophthalmol 2013, 2013:343560.

39. Pinazo-Duran MD, Zanon-Moreno V, Garcia-Medina JJ, Gallego-Pinazo R: Evaluation of presumptive biomarkers of oxidative stress, immune response and apoptosis in primary open-angle glaucoma. Curr Opin Pharmacol 2013, 13:98-107.

40. Nita M, Grzybowski A, Ascaso FJ, Huerva V: Age-related macular degeneration in the aspect of chronic low-grade inflammation (pathophysiological parainflammation). Mediators Inflamm 2014, 2014:930671.

41. Krizaj D, Ryskamp DA, Tian N, Tezel G, Mitchell CH, Slepak VZ, Shestopalov VI: From mechanosensitivity to inflammatory responses: new players in the pathology of glaucoma. Curr Eye Res 2014, 39:105-119.

42. Abcouwer SF, Lin CM, Shanmugam S, Muthusamy A, Barber AJ, Antonetti DA: Minocycline prevents retinal inflammation and vascular permeability following ischemia-reperfusion injury. J Neuroinflammation 2013, 10:149.

43. Hartong DT, Berson EL, Dryja TP: Retinitis pigmentosa. Lancet 2006, 368:1795-1809.
44. Zeiss CJ, Johnson EA: Proliferation of microglia, but not photoreceptors, in the outer nuclear layer of the rd-1 mouse. Invest Ophthalmol Vis Sci 2004, 45:971-976.

45. Zeng HY, Zhu XA, Zhang C, Yang LP, Wu LM, Tso MO: Identification of sequential events and factors associated with microglial activation, migration, and cytotoxicity in retinal degeneration in rd mice. Invest Ophthalmol Vis Sci 2005, 46:2992-2999.

46. Peng B, Xiao J, Wang K, So KF, Tipoe GL, Lin B: Suppression of microglial activation is neuroprotective in a mouse model of human retinitis pigmentosa. J Neurosci 2014, 34:8139-8150.

47. Hughes EH, Schlichtenbrede FC, Murphy CC, Broderick C, van Rooijen N, Ali RR, Dick AD: Minocycline delays photoreceptor death in the rds mouse through a microglia-independent mechanism. Exp Eye Res 2004, 78:1077-1084.

48. Schmid $H$, Herrmann $T$, Kohler $K$, Stett A: Neuroprotective effect of transretinal electrical stimulation on neurons in the inner nuclear layer of the degenerated retina. Brain Res Bull 2009, 79:15-25.

49. Roesch K, Stadler MB, Cepko CL: Gene expression changes within Muller glial cells in retinitis pigmentosa. Mol Vis 2012, 18:1197-1214.

50. Gupta N, Brown KE, Milam AH: Activated microglia in human retinitis pigmentosa, late-onset retinal degeneration, and age-related macular degeneration. Exp Eye Res 2003, 76:463-471.

51. Sasahara M, Otani A, Oishi A, Kojima H, Yodoi Y, Kameda T, Nakamura H, Yoshimura N: Activation of bone marrow-derived microglia promotes photoreceptor survival in inherited retinal degeneration. Am J Pathol 2008, 172:1693-1703.

52. Ebert S, Weigelt K, Walczak Y, Drobnik W, Mauerer R, Hume DA, Weber BH, Langmann T: Docosahexaenoic acid attenuates microglial activation and delays early retinal degeneration. J Neurochem 2009, 110:1863-1875.

53. Sheets KG, Jun B, Zhou Y, Zhu M, Petasis NA, Gordon WC, Bazan NG: Microglial ramification and redistribution concomitant with the attenuation of choroidal neovascularization by neuroprotectin D1. Mol Vis 2013, 19:1747-1759.

54. Roque RS, Imperial CJ, Caldwell RB: Microglial cells invade the outer retina as photoreceptors degenerate in Royal College of Surgeons rats. Invest Ophthalmol Vis Sci 1996, 37:196-203.

55. Gehrig A, Langmann T, Horling F, Janssen A, Bonin M, Walter M, Poths S, Weber $\mathrm{BH}$ : Genome-wide expression profiling of the retinoschisin-deficient retina in early postnatal mouse development. Invest Ophthalmol Vis Sci 2007, 48:891-900.

56. Nishida T, Shibuya E, Asukata $Y$, Nakamura S, Ishihara M, Hayashi K, Takeno M, Ishigatsubo Y, Mizuki N: Clinical course before and after cataract and glaucoma surgery under systemic infliximab therapy in patients with Behcet's disease. Case Rep Ophthalmol 2011, 2:189-192.

57. Roh M, Zhang Y, Murakami Y, Thanos A, Lee SC, Vavvas DG, Benowitz LI, Miller JW: Etanercept, a widely used inhibitor of tumor necrosis factor-alpha (TNF-alpha), prevents retinal ganglion cell loss in a rat model of glaucoma. PLoS One 2012, 7:e40065.

58. Abcouwer SF, Lin CM, Wolpert EB, Shanmugam S, Schaefer EW, Freeman WM Barber AJ, Antonetti DA: Effects of ischemic preconditioning and bevacizumab on apoptosis and vascular permeability following retinal ischemia-reperfusion injury. Invest Ophthalmol Vis Sci 2010, 51:5920-5933.

59. Markomichelakis NN, Theodossiadis PG, Sfikakis PP: Regression of neovascular age-related macular degeneration following infliximab therapy. Am J Ophthalmol 2005, 139:537-540.

60. Sahaboglu A, Tanimoto N, Kaur J, Sancho-Pelluz J, Huber G, Fahl E, Arango-González B, Zrenner E, Ekstrom P, Lowenheim H, Seeliger M Paquet-Durand F: PARP1 gene knock-out increases resistance to retinal degeneration without affecting retinal function. PLoS One 2010, 5:e15495.

61. Vallazza-Deschamps G, Cia D, Gong J, Jellali A, Duboc A, Forster V, Sahel JA, Tessier LH, Picaud S: Excessive activation of cyclic nucleotide-gated channels contributes to neuronal degeneration of photoreceptors. Eur J Neurosci 2005, 22:1013-1022.

62. Erdelyi K, Bai P, Kovacs I, Szabo E, Mocsar G, Kakuk A, Szabo C, Gergely P, Virag L: Dual role of poly(ADP-ribose) glycohydrolase in the regulation of cell death in oxidatively stressed A549 cells. FASEB J 2009, 23:3553-3563.

63. D'Amours D, Sallmann FR, Dixit VM, Poirier GG: Gain-of-function of poly (ADP-ribose) polymerase-1 upon cleavage by apoptotic proteases: implications for apoptosis. J Cell Sci 2001, 114:3771-3778.

64. Fernandez-Bueno I, Garcia-Gutierrez MT, Srivastava GK, Gayoso MJ, Gonzalo-Orden JM, Pastor JC: Adalimumab (tumor necrosis factor-blocker) reduces the expression of glial fibrillary acidic protein immunoreactivity 
increased by exogenous tumor necrosis factor alpha in an organotypic culture of porcine neuroretina. Mol Vis 2013, 19:894-903.

65. Arroba Al, Alvarez-Lindo N, Van Rooijen N, De la Rosa EJ: Microglia-Muller glia crosstalk in the rd10 mouse model of retinitis pigmentosa. Adv Exp Med Biol 2014, 801:373-379.

66. Zhao T, Li Y, Weng C, Yin Z: The changes of potassium currents in RCS rat Muller cell during retinal degeneration. Brain Res 2012, 1427:78-87.

67. Iandiev I, Biedermann B, Bringmann A, Reichel MB, Reichenbach A, Pannicke T: Atypical gliosis in Muller cells of the slowly degenerating rds mutant mouse retina. Exp Eye Res 2006, 82:449-457.

68. Huo SJ, Li Y, Raisman G, Yin ZQ: Transplanted olfactory ensheathing cells reduce the gliotic injury response of Muller cells in a rat model of retinitis pigmentosa. Brain Res 2011, 1382:238-244.

69. Phillips MJ, Otteson DC, Sherry DM: Progression of neuronal and synaptic remodeling in the $\mathrm{rd} 10$ mouse model of retinitis pigmentosa. J Comp Neurol 2010, 518:2071-2089.

70. Komeima K, Rogers BS, Lu L, Campochiaro PA: Antioxidants reduce cone cell death in a model of retinitis pigmentosa. Proc Natl Acad Sci U S A 2006, 103:11300-11305.

71. Shen J, Yang X, Dong A, Petters RM, Peng YW, Wong F, Campochiaro PA: Oxidative damage is a potential cause of cone cell death in retinitis pigmentosa. J Cell Physiol 2005, 203:457-464.

72. Usui S, Komeima K, Lee SY, Jo YJ, Ueno S, Rogers BS, Wu Z, Shen J, Lu L, Oveson BC, Rabinovitch PS, Campochiaro PA: Increased expression of catalase and superoxide dismutase 2 reduces cone cell death in retinitis pigmentosa. Mol Ther 2009, 17:778-786.

73. Keller JN, Hanni KB, Gabbita SP, Friebe V, Mattson MP, Kindy MS: Oxidized lipoproteins increase reactive oxygen species formation in microglia and astrocyte cell lines. Brain Res 1999, 830:10-15.

74. Roy A, Jana A, Yatish K, Freidt MB, Fung YK, Martinson JA, Pahan K: Reactive oxygen species up-regulate $C D 11 \mathrm{~b}$ in microglia via nitric oxide: implications for neurodegenerative diseases. Free Radic Biol Med 2008, 45:686-699.

75. Tsai GY, Cui JZ, Syed H, Xia Z, Ozerdem U, McNeil JH, Natsubara JA: Effect of $\mathrm{N}$-acetylcysteine on the early expression of inflammatory markers in the retina and plasma of diabetic rats. Clin Experiment Ophthalmol 2009, $37: 223-231$

doi:10.1186/s12974-014-0172-9

Cite this article as: Martínez-Fernández de la Cámara et al: Infliximab reduces Zaprinast-induced retinal degeneration in cultures of porcine retina. Journal of Neuroinflammation 2014 11:172.

\section{Submit your next manuscript to BioMed Central and take full advantage of:}

- Convenient online submission

- Thorough peer review

- No space constraints or color figure charges

- Immediate publication on acceptance

- Inclusion in PubMed, CAS, Scopus and Google Scholar

- Research which is freely available for redistribution 